\title{
DRIP IRRIGATION MANAGEMENT FOR WHEAT PRODUCTION IN SANDY SOIL USING NUCLEAR TECHNIQUE UNDER SALINITY CONDITIONS.
}

\author{
El-Tohory S. K. ${ }^{1}$, M. F. Kassab ${ }^{1}$, A. M. El-Gindy ${ }^{2}$ and \\ K. F. EL-Bagoury ${ }^{2}$
}

\begin{abstract}
A field experiment was conducted in the experimental farm of Soil and Water Research Department, Nuclear Research Center, Atomic Energy Authority. Soil mulching and drip irrigation system are strategies for saving irrigation water. This trail was carried out during 2014/2015 winter season in Egypt to evaluate the effects of soil mulching and drip irrigation system on combating salinity and in the same time improving the yield and water-use efficiency by grown wheat crop (Triticum aestivum L.) cv Masr 2 variety in sandy soil. Treatments of water salinity,

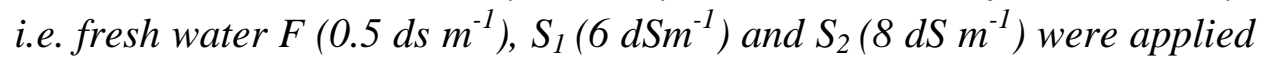
under mulching (rice straw) or non-mulching soil. Each treatment was irrigated twice a week using a total amount of $440 \mathrm{~mm}$ during the growing season. Volumetric water content was measured using the neutron scattering technique to detect the soil wettability during the growing season. In general, wheat yield for non-mulched treatment irrigated by fresh water was (9.43Ardab.fad ${ }^{-1}$ ) or $3366 \mathrm{Kg}_{\mathrm{ha}} \mathrm{h}^{-1}$ higher than the mulched one irrigated with fresh water $\left(9.04 \mathrm{Ardab}_{\mathrm{fad}}{ }^{-1}\right)$ or $3227 \mathrm{Kg} . \mathrm{ha}^{-1}$ and also, it was higher than both mulched and non-mulched treatments irrigated with saline water of 6 and $8 \mathrm{dS} . \mathrm{m}^{-1}$. Under saline irrigation, the wheat yield and water use efficiency of mulched treatments were higher than the non-mulched ones for both 6 and $8 \mathrm{dS} . \mathrm{m}^{-1}$. In nonmulched conditions, the treatment irrigated by $6 \mathrm{dS} . \mathrm{m}^{-1}$ recorded a higher production (6.75 Ardab. $\mathrm{fad}^{-1}$ ) or $2411 \mathrm{Kg}_{\mathrm{g}} \mathrm{ha}^{-1}$ than the one irrigated by 8 dS. $\mathrm{m}^{-1}$ (6.25 Ardab. $\left.\mathrm{fad}^{-1}\right)$ or $2231 \mathrm{Kg} . \mathrm{ha}^{-1}$ in the same sequence mulched

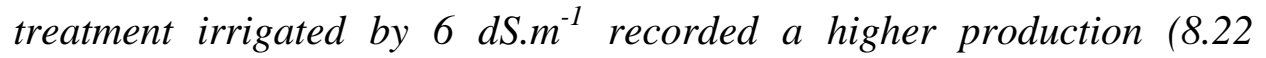
Ardab. $\left.\mathrm{fad}^{-1}\right)$ or $2936 \mathrm{Kg} . \mathrm{ha}^{-1}$ than the mulched one irrigated by $8 \mathrm{dS} . \mathrm{m}^{-1}$

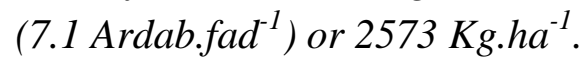

1 Soil and Water Research Department, Nuclear Research Center, Atomic Energy Authority. 2 Agricultural Engineering Department, Faculty of Agriculture, Ain Shams University. 
The above results indicated that surface mulching could improve the growth and yield of wheat especially under saline irrigation by reducing soil evaporation which sustains soil wetness that enhances the wheat ability to combat salinity stress.

Keywords: Mulching, Drip irrigation, salinity, wheat, Water use efficiency, Neutron scattering

\section{INTRODUCTION}

$\mathrm{N}$ owadays, the use of non-conventional water resources is becoming a reality. The use of saline or sodic water in agriculture increases the total volume of irrigation water in many areas. Soil management is essential for preventing adverse impacts when irrigating with saline sodic water.The success of saline water use in irrigation requires the development of new scientific practices, new guidelines for use that cope with the prevailing local conditions and new strategies that facilitate its use on a relatively large scale (Hamdy, 2005). In Egypt agriculture uses approximately $85 \%$ of the fresh water resources. In spite of water scarcity and the fact that Egypt's share in the Nile waters is predetermined, water-use efficiency is low, due to high water losses (FAO, 2012). Direct evaporation from soil is often a major loss of available water because it is not contributing to biomass production. Reducing evaporation can help conserve soil moisture, save irrigation water, and reduce salt accumulation in surface layer of the soil (Yamanaka et al., 2004). There is usually no single method to achieve safe use of saline water in irrigation. Many different approaches and practices can be combined into satisfactory saline water irrigation systems. Increasing irrigation water salinity increased salt concentration and osmotic potential in the root zone. However, due to nature of drip irrigation, frequent water applications maintained the soil water content in the root zone in the first $50 \%$ of the available water thus reduced the effect of osmotic potential on water uptake. Generally, profile salt concentration increased with increasing salinity of irrigation water used. Higher salt concentration in the top layer is due to high evaporation rate from the wetted surface (Yazar et al., 2015). Wheat (Triticum aestivum L.) is one of the most important crops worldwide. It is main crop in 
winter season for more than 7000 years in Egypt and considered to be a strategic commodity. It provides more than one-third of the daily caloric intake, grains as food for human and straw as fodder for animals. The cultivated fields with wheat supply only $40 \%$ of its annual domestic demand of Egyptians. Therefore, the field production should be increased to cover the demanded consumption (El-Shabrawi et al., 2015). In this regard, Gaber (2000) explained that the highest values of water use efficiency concerning wheat grains, straw and total yield (1.96, 3.22 and $5.18 \mathrm{~kg} / \mathrm{m}^{3}$, respectively ) were resulted in by adding $507.9 \mathrm{~mm}$ of irrigation water per season to Giza 163 wheat variety. Araguiés and Teresa, (2014) said that soil mulching is a sensible strategy to reduce evaporation, accelerate crop development, reduce erosion and assist in weed control, but its efficiency for soil salinity control is not as well documented.

The aim of the study:

- Studying the effect of saline water and mulching strategy on wheat crop productivity under drip irrigation system in sandy soil

- Evaluating the effect of saline water and using organic mulching on wheat yield, emission uniformity, water use efficiency, harvest index, water content in the soil profile and soil salinity during the grown season.

\section{MATERIALS AND METHODS}

\section{1- Materials:}

A field experiment was conducted in the experimental farm of Soil and Water Research Department, Nuclear Research Center, Atomic Energy Authority, Egypt. The site is situated at $30^{\circ} 24^{`} \mathrm{~N}, 31^{\circ} 35^{`} \mathrm{E}$, respectively, while the altitude is $20 \mathrm{~m}$ above the sea level.

\section{Physical and chemical analysis of soil:}

Sandy soil samples were collected, before cultivation to determine some of the physical and chemical characteristics of the experimental soil (Tables 1 and 2); all soil chemical and physical characteristics were carried out according to Carter and Gregoreish (2008). 


\begin{tabular}{|c|c|c|c|c|c|c|}
\hline \multicolumn{2}{|c|}{ Table 1: Some physical properties of experimental soil. } \\
\hline \multirow{2}{*}{$\begin{array}{c}\text { Soil depth } \\
(\mathrm{cm})\end{array}$} & Particle size distribution $\%$ & $\begin{array}{c}\text { Bulk } \\
\text { density } \\
\mathrm{g} / \mathrm{cm}^{3}\end{array}$ & $\begin{array}{c}\text { Texture } \\
\text { class }\end{array}$ & $\begin{array}{c}\text { Total } \\
\text { porosity } \\
\mathrm{cm}^{3} \mathrm{~cm}^{-3}\end{array}$ \\
\hline 15 & 95.47 & 1.60 & 2.93 & 1.60 & Sand & 0.39 \\
\hline 30 & 94.40 & 4.00 & 1.60 & 1.55 & Sand & 0.41 \\
\hline 50 & 97.07 & 0.80 & 2.13 & 1.54 & Sand & 0.42 \\
\hline 70 & 97.07 & 0.53 & 2.40 & 1.59 & Sand & 0.40 \\
\hline 90 & 97.33 & 0.27 & 2.40 & 1.53 & Sand & 0.42 \\
\hline
\end{tabular}

\begin{tabular}{|c|c|c|c|c|c|c|c|c|c|}
\hline \multirow{2}{*}{$\begin{array}{l}\text { Depth } \\
(\mathrm{cm})\end{array}$} & \multirow{2}{*}{$\begin{array}{c}\mathrm{pH} \\
(1: 2.5)\end{array}$} & \multirow{2}{*}{$\begin{array}{c}\mathrm{EC}_{\mathrm{e}} \\
\left(\mathrm{dS} \mathrm{\textrm {m } ^ { - 1 }}\right)\end{array}$} & \multicolumn{3}{|c|}{$\begin{array}{l}\text { Soluble anions } \\
\quad\left(\mathrm{meq}^{-1}\right)\end{array}$} & \multicolumn{4}{|c|}{ Soluble cations (meq $1^{-1}$ ) } \\
\hline & & & $\mathrm{Cl}$ & $\mathrm{HCO}_{3}^{-}$ & $\mathrm{SO}_{4}^{--}$ & $\mathrm{Ca}^{++}$ & $\mathrm{Mg}^{++}$ & $\mathrm{Na}^{+}$ & $\mathrm{K}^{+}$ \\
\hline $0-15$ & 7.9 & 0.46 & 1.5 & 1.3 & 1.8 & 1.3 & 0.6 & 2 & 0.7 \\
\hline $15-30$ & 8.1 & 0.45 & 1.3 & 1.4 & 1.8 & 1.3 & 0.4 & 2.2 & 0.6 \\
\hline $30-50$ & 8.0 & 0.44 & 1.3 & 1.6 & 1.5 & 1.7 & 0.4 & 1.8 & 0.5 \\
\hline $50-70$ & 8.2 & 0.42 & 1.3 & 1.7 & 1.2 & 1.5 & 0.6 & 1.7 & 0.4 \\
\hline $70-90$ & 8.3 & 0.53 & 1.4 & 1.3 & 2.6 & 1.7 & 0.9 & 2.2 & 0.5 \\
\hline
\end{tabular}

\section{Meteorological data:}

The meteorological data used according to Center Laboratory for Agricultural Climate (CLAC) such Reference evapotranspiration (ETo), the maximum and the minimum temperature and the maximum and the minimum relative humidity. The applied weather data are presented in Fig. (1).

\section{Wheat crop:}

Grains of wheat crop (Triticum astivum L.) variety Masr 2. were provided by Wheat Department, Field Crops Research Institute, Agriculture Research Center (ARC), Giza, Egypt. Seeds were sown on December 1, 2014 and mature plants were harvested on April 23, 2016, which completing the growth duration period of 144 days. Whereas, obtaining the crop coefficient value $(\mathrm{Kc})$ of wheat (Table 3), and the active root depth for spring wheat is 0.9 to $1.5 \mathrm{~m}$ and spreads of $0.15-0.25 \mathrm{~m}$, were obtained from the publication data of FAO (Doorenbos and Kassam, 1979). 

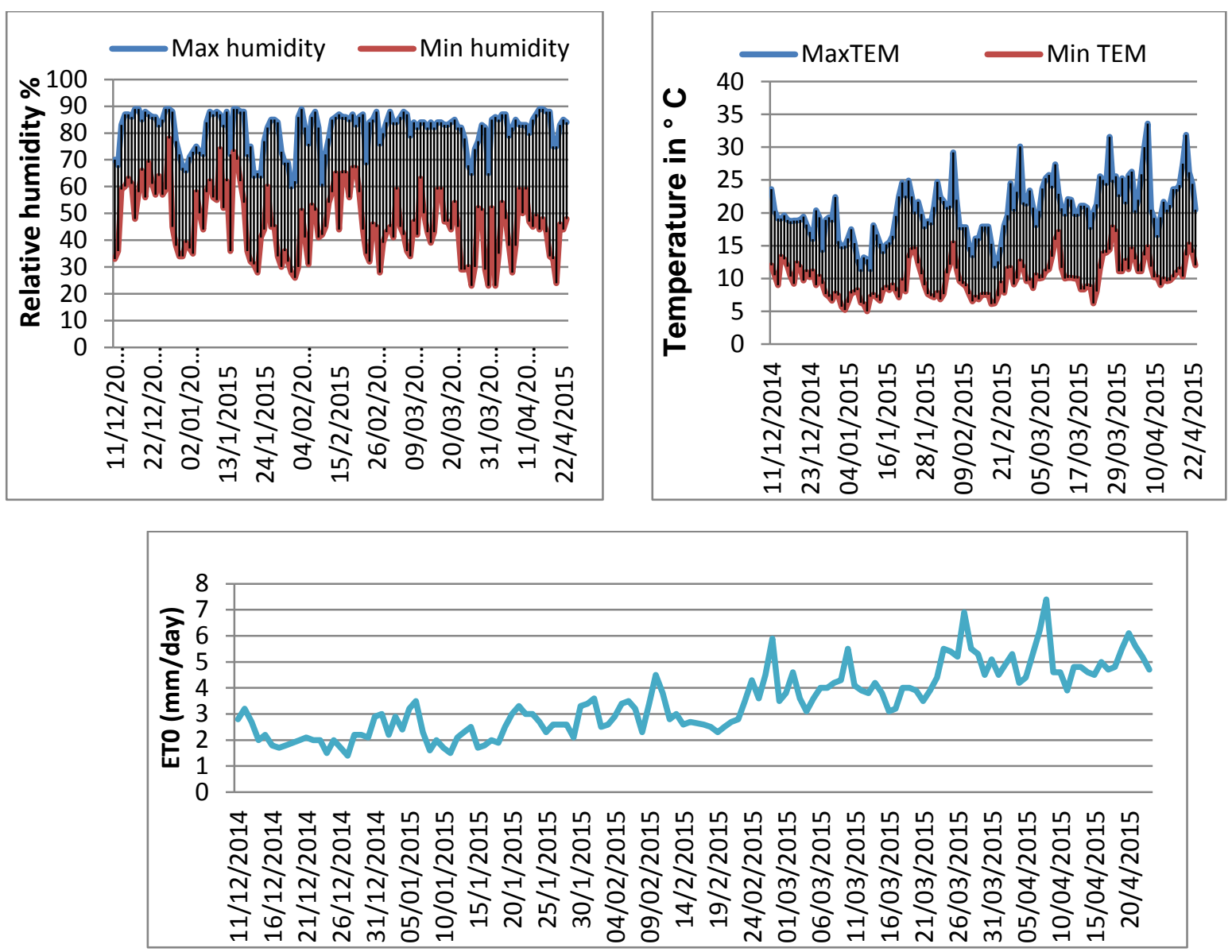

Figure (1): The meteorological data according to Center Laboratory for Agricultural Climate (CLAC)

Recommended doses of NPK fertilizers were applied according to the recommendations of the Ministry of Agriculture and Land Reclamation, Egypt. The soil surface was leveled and mineral fertilizers were applied at the rate of $286 \mathrm{~kg} \mathrm{~N} \mathrm{ha}^{-1}$ in the form of urea, $71.5 \mathrm{~kg} \mathrm{P}_{2} \mathrm{O}_{5} \mathrm{ha}^{-1}$ and $57 \mathrm{~kg}$ $\mathrm{K}_{2} \mathrm{O}$ ha $^{-1}$. Venturi injector was used for injecting chemical fertilizers.

\begin{tabular}{|c|c|c|c|c|}
\hline \multicolumn{5}{|c|}{ Table 3: The crop parameters for average demand conditions for wheat } \\
crop according to FAO Irrigation and Drainage Paper No.33 \\
\hline Stage & Initial stage & Development stage & Mid stage & Late stage \\
\hline Date from & $1 / 12 / 2014$ & $21 / 12 / 2014$ & $9 / 2 / 2015$ & $26 / 3 / 2015$ \\
To & $20 / 12 / 2014$ & $8 / 2 / 2015$ & $25 / 3 / 2015$ & $24 / 4 / 2015$ \\
\hline Stage length (d) & 20 & 50 & 45 & 30 \\
\hline Crop coefficient $(\mathrm{Kc})$ & 0.40 & 0.80 & 1.20 & 0.70 \\
\hline
\end{tabular}




\section{Water source}

Treatments of water salinity, i.e. fresh water $\mathrm{F}\left(0.5 \mathrm{ds} \mathrm{m}^{-1}\right), \mathrm{S}_{1}\left(6 \mathrm{dSm}^{-1}\right)$ and $\mathrm{S}_{2}\left(8 \mathrm{dS} \mathrm{m}^{-1}\right)$ were applied under mulching (rice straw) or nonmulching soil. The saline irrigation water was prepared by mixing fresh water with natural salt collected from (salt pans) to reach the desired concentration 6 and $8 \mathrm{dS} \cdot \mathrm{m}^{-1}$ as shown in Fig. (2). Electrical conductivity of water and soil (in a saturated paste extract) was measured using EC meter. Irrigation with saline water started at the end of seedling establishment stage where seedling thinning took place to assure high germination percentage and healthy seedlings (Dayyoub et al., 2007). Plants were irrigated twice a week.

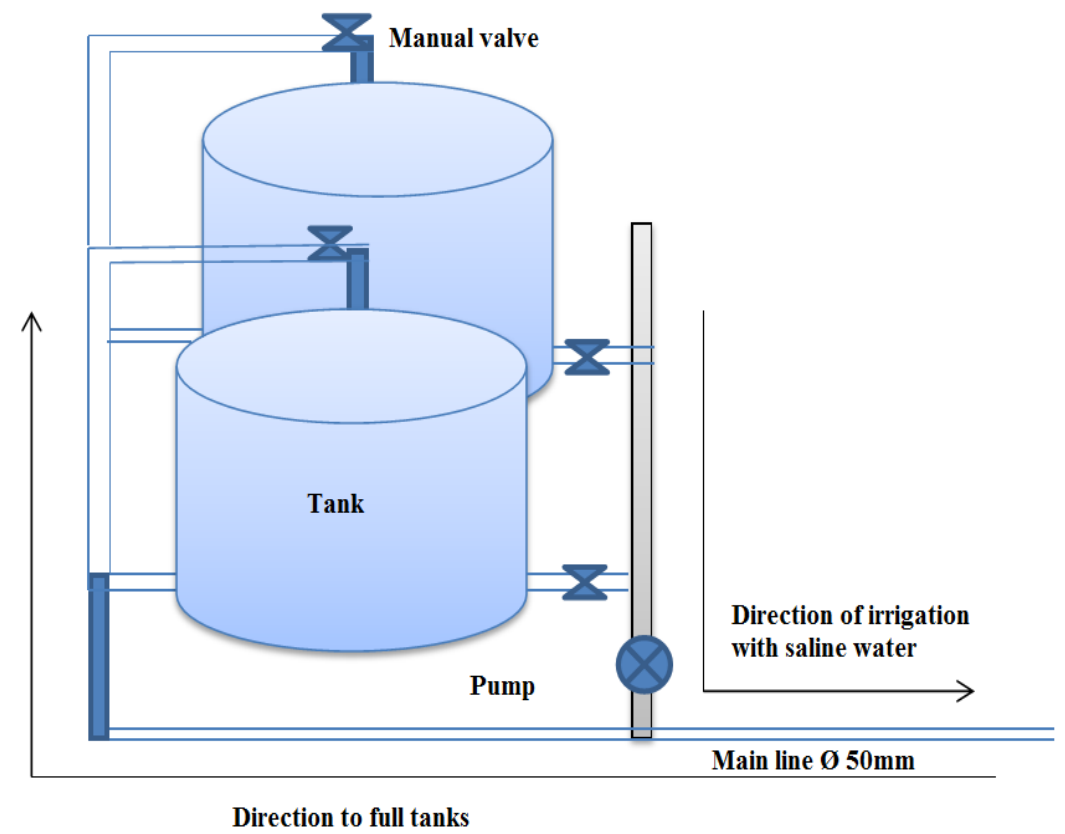

Fig. (2): Mechanical design to mix natural salt with fresh water.

\section{Irrigation system:}

Drip irrigation system was used to irrigate wheat plants the system consists of the following components as shown in Fig. (3):-

- PVC pipes 50mm diameter of main and sub main lines 6 bar pressure.

- Lateral tubes $16 \mathrm{~mm}$ diameter of polyethylene (PE) were putted at spacing of $30 \mathrm{~cm}$.

- Built- in drip line emitter at $30 \mathrm{~cm}$ spacing with manufacturing discharge of $4 \mathrm{~L} \mathrm{hr}^{-1}$. 
- The pump was 220-240 volt, 4.33 Ampere and 0.00KW power, $3 \mathrm{r} 001 / \mathrm{hr}$ and ${ }^{\mathrm{T}} \mathrm{T} \mathrm{bar}$.

- Plastic tanks of 2000 liter capacity used to apply the needed amount of saline irrigation water.

- PVC Ball valves to control the amounts of irrigation water.

- Commercial pressure gage range up 0 to10 bar.

- Water meters were used to measure the volume of water used (liter or cubic meter).

- Venturi injector was used for injecting chemicals fertilizers.

- Neutron access tubes were installed to $100 \mathrm{~cm}$ depth in the middle of each treatment for three replicates.

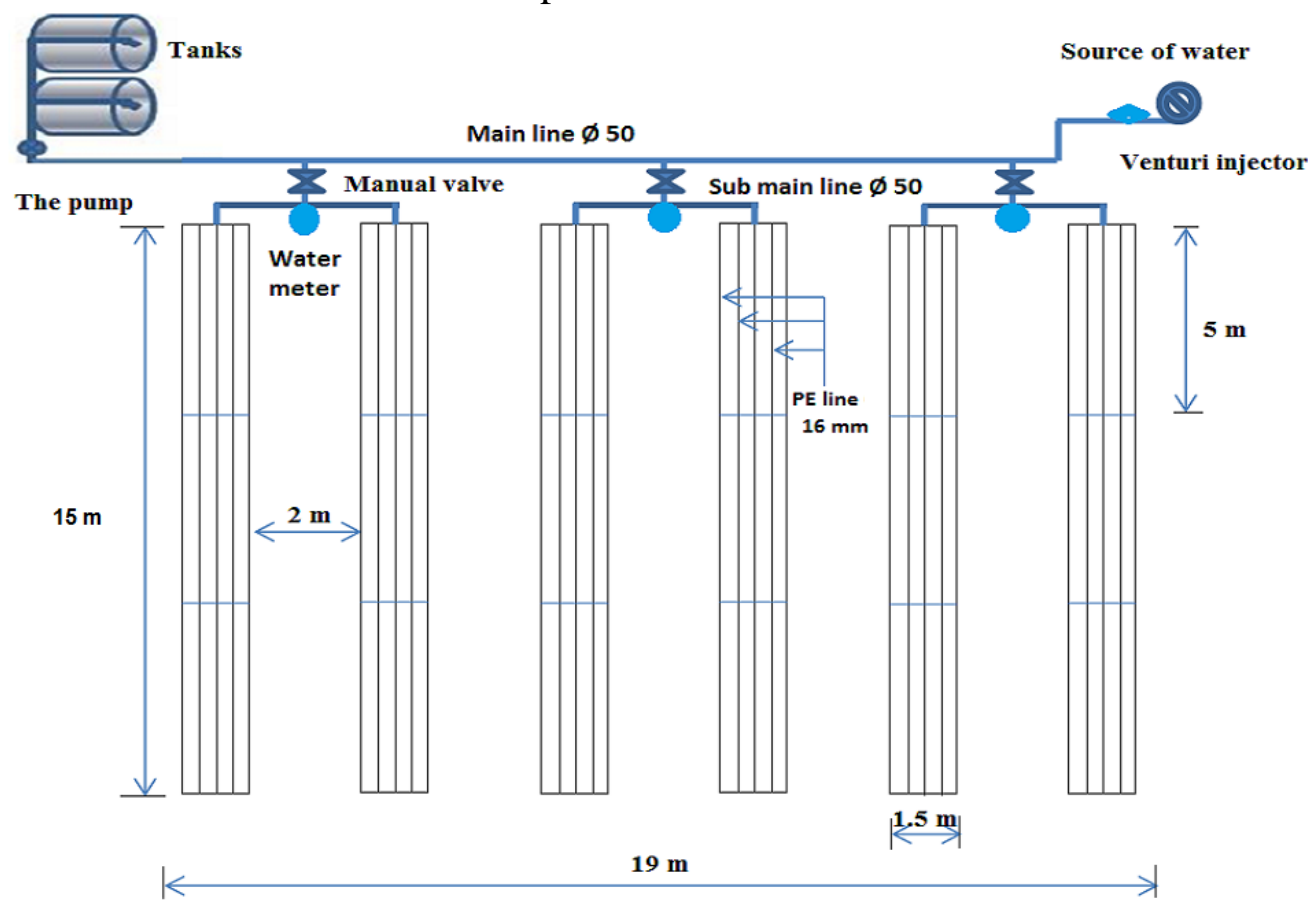

Fig. 3: Layout of the experimental drip irrigation design

\section{2-2 Methods:}

\section{2-2-1 Crop evapotranspiration (ETc):}

Crop evapotranspiration (ETc) $\left[\mathrm{mm} \mathrm{day}^{-1}\right]$ is calculated by multiplying the reference crop evapotranspiration, daily (ETo) $\left[\mathrm{mm} \mathrm{day}^{-1}\right]$ (according to center laboratory for agriculture climate), by a crop coefficient, $\mathrm{Kc}$ (Allen et al., 2006).

$$
\mathrm{ETc}=\mathrm{KC} * \mathrm{ETo}
$$




\section{2-2-2 Emission uniformity (EU) of the drip irrigation system:}

The drip irrigation system (DIS) was evaluated in terms of emission uniformity (EU), which is determined by measuring the volume of water discharged by every emitter during a definite time, and calculated using the following equation (Keller and Karmeli, 1974):

$$
\boldsymbol{E U}=\frac{\boldsymbol{Q}_{n}}{\boldsymbol{Q}_{a}} * 100
$$

Where: (EU: Emission uniformity (\%), $Q_{n}$ : Mean of the lowest quarter of discharge of the selected emitters $\left(1 \mathrm{hr}^{-1}\right)$ and $Q_{a}$ : Mean of the total discharge emitters rate $\left.\left(1 \mathrm{hr}^{-1}\right)\right)$.The EU value for drip irrigation system is good (89.6\%) according to (Merriam and Keller 1978).

\section{2-2-3 Water use efficiency (WUE):}

Water use efficiency (WUE) was calculated using the following equation according to Kang et al., (2002).

$$
\mathrm{WUE}=\frac{\mathrm{Gy}}{\mathrm{ET}}
$$

Where, WUE: Water use efficiency $\left(\mathrm{kg} \cdot \mathrm{m}^{-3}\right)$, Gy: Grain yield $\left(\mathrm{kg} \cdot \mathrm{ha}^{-1}\right)$ and ET is the total evapotranspiration $\left(\mathrm{m}^{3} \cdot \mathrm{ha}^{-1}\right)$

\section{2-2-4 Harvest index (HI):}

Harvest index was calculated by using the following formula after (Ali $\boldsymbol{e t}$ al., 2010 and Kang et al., 2002):

$$
\text { H.I }=\frac{\text { Grain yield }\left(\text { t.ha }^{-1}\right)}{\text { Biological yield }\left(\text { t.ha }^{-1}\right)}
$$

\section{2-2-5 Field calibration of neutron moisture meter (NMM):}

Neuron calibration curves at different soil depths were determined for the soil using neutron moisture meter CPN, 50mCi. (503 DR hydro probe) Americium -241Beryllium source according to IAEA (2008). The neutron probe was calibrated based on the procedure given in the user manual (Model 503DR CPN Hydro probe) Shenkut et al., (2013). Two plots with mulching and without mulching $(1 \times 1 \mathrm{~m})$ for each were selected randomly on an experimental field that had been under access tube was installed on each plot and installed at the depth of $105 \mathrm{~cm}$. Irrigation water was added on the plots until saturated at depth. NMM count rates were measured at depths of 30,50,70 and $90 \mathrm{~cm}$; also, in the same time soil samples were taken from two plots and measured by drying samples at $105{ }^{0} \mathrm{C}$ for 24 hours. Wet and dry points were established to obtain a wide range of moisture contents and to make 
it possible for the probe to read these ranges, Probe readings in the tube in count ratio or rat unit and volume sampler in the probe reading in count ratio (rat) versus the volume sample data was plotted and entered into an Excel spread sheet, and a trend line created with its slope and intercept, and displayed its $\mathrm{R}^{2}$ value. The coefficients of the linear equation ( $a$ and $b$ ) obtained from the fitted curves were used to convert the neutron probe readings to soil moisture readings (Shenkut et al., 2013). Then the volumetric moisture content (VMC) was measured at $(30,50,70$ and $90 \mathrm{~cm})$ in each plot before and after irrigation events. The moisture content of the surface layer $(15 \mathrm{~cm}$ depth) was measured by drying samples at $105{ }^{0} \mathrm{C}$ for 24 hours. Figs. (4\&5) show that the regression equations of neutron calibration curves at different soil depths for the mulched and non-mulched treatments which performed in order to detect the soil moisture content. Measurements did not show difference between both calibrations, so both calibrations were valid.
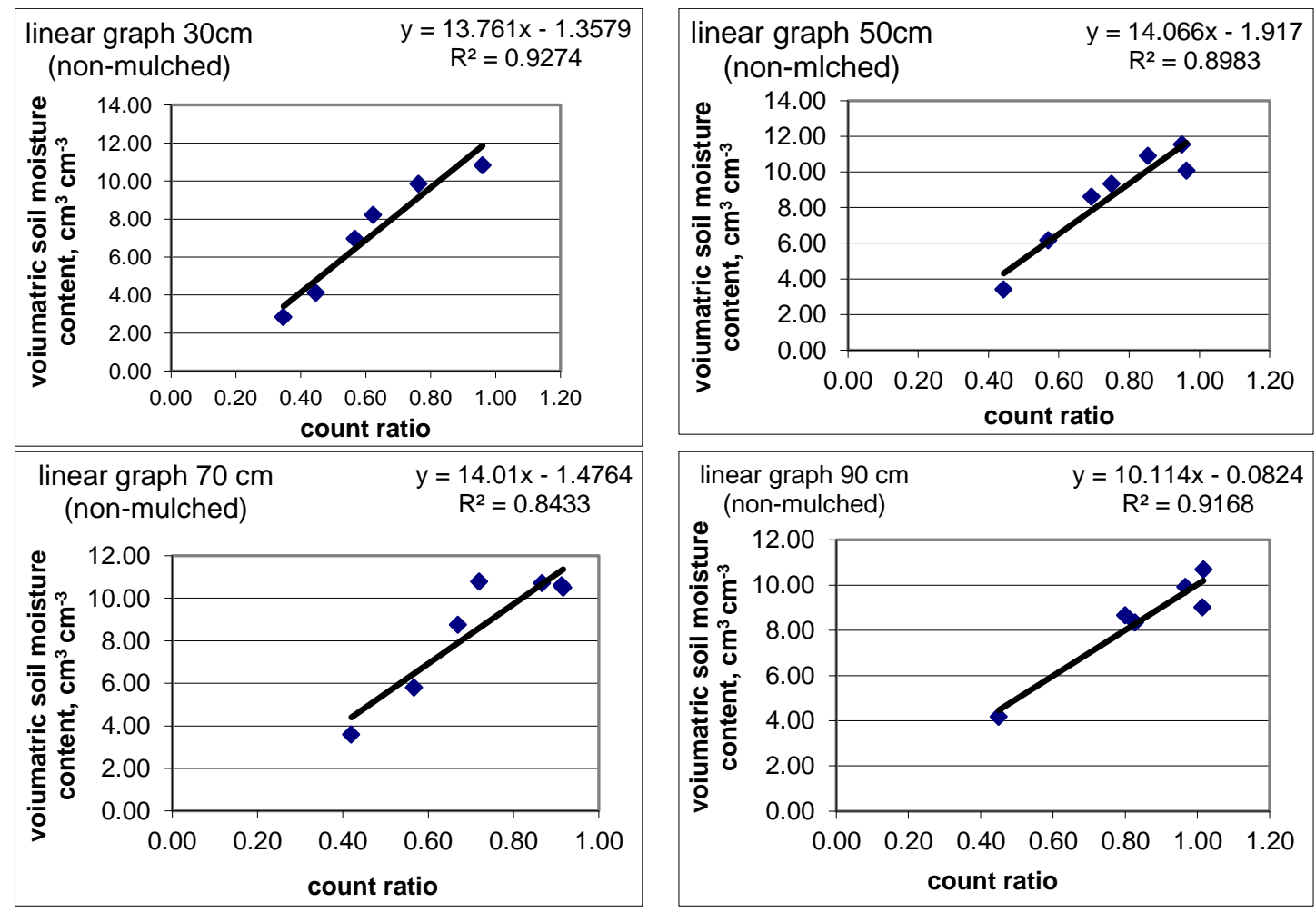

Fig. (4): Regression equations of neutron calibration curves at different soil depths of the non- mulched treatments under study. 

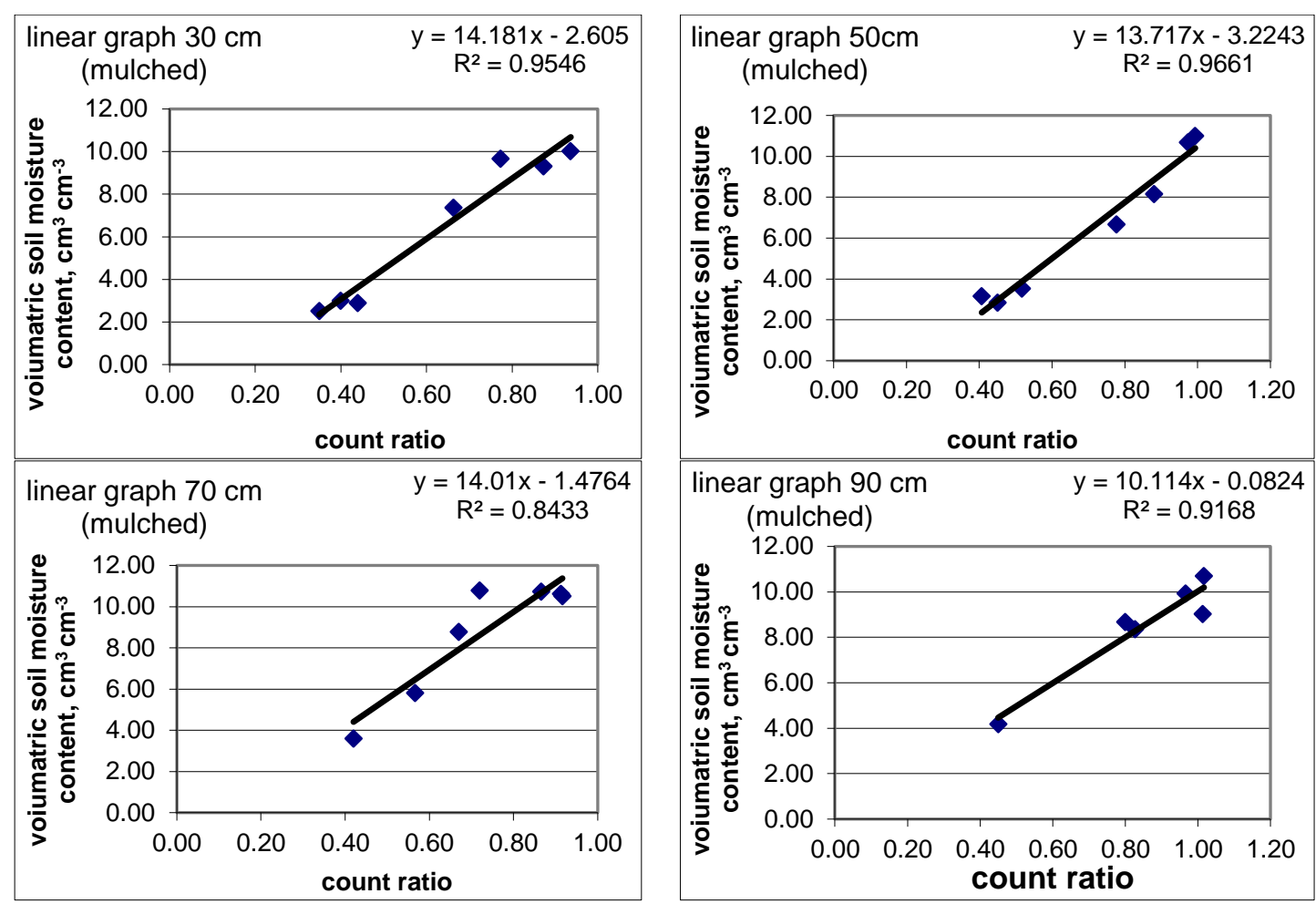

Fig. (5): Regression equations of neutron calibration curves at different soil depths of the mulched treatments under study.

\section{Experimental design:}

The experiment design was Two Factor Randomized Complete Block Design with three replicates consist of two variable factors: mulching by rice straw and without mulching and water salinity levels fresh water $\mathrm{F}$ $\left(0.5 \mathrm{dS} \mathrm{m}^{-1}\right), \mathrm{S} 1\left(6 \mathrm{dS} \mathrm{m}^{-1}\right)$ and $\mathrm{S}_{2}\left(8 \mathrm{dS} \mathrm{m}^{-1}\right)$.

- The main plot treatments were the irrigation water quality and subplot treatments were mulched (FC, S1C, S2C) and non-mulched (FUN, S1UN, S2UN) treatments.

- Each treatment consisted of three replicates were irrigated by fresh water (F), saline water of (S1) $6 \mathrm{dS} \cdot \mathrm{m}^{-1}$ and (S2) $8 \mathrm{dS} \cdot \mathrm{m}^{-1}$.

- Mulching with rice straw was used at rate of $4 \mathrm{t} \mathrm{ha}^{-1}$ according to Sarwar et al., (2013).

- Treatments were arranged and distributed in 18 plots. Each plot area was $7.5 \mathrm{~m}^{2}\left(1.5 * 5 \mathrm{~m}^{2}\right)$ with 5 drip laterals and spacing between $30 \mathrm{~cm}$ as shown in Fig. (6). 


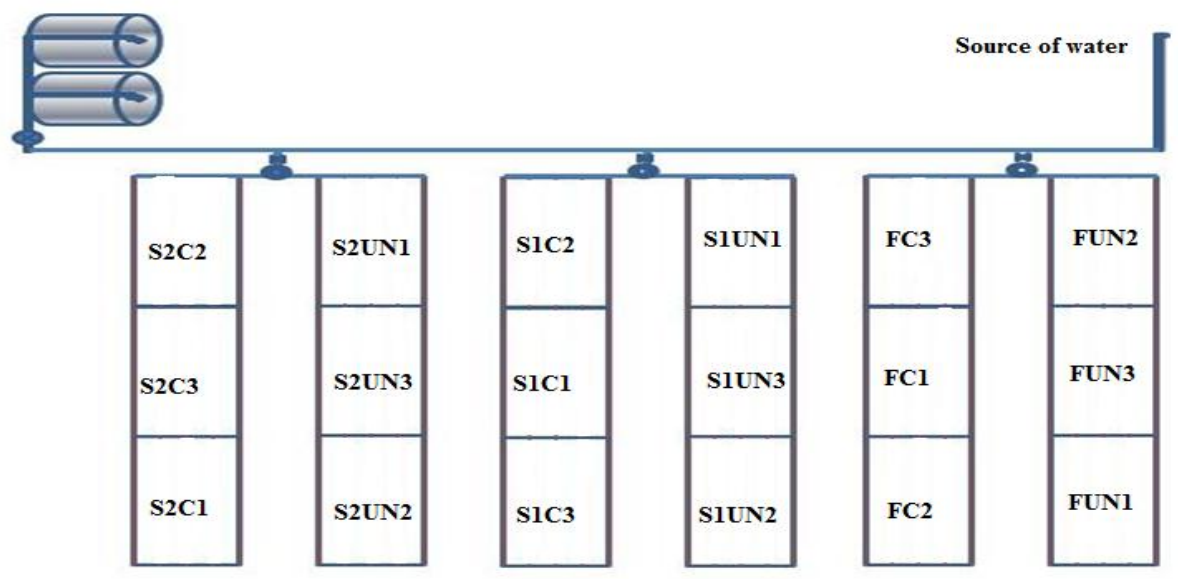

FUN: Fresh water without mulching

FC: Fresh water with mulching

S1UN: Saline water with $6 \mathrm{dsm}^{-1}$, without mulching. $\quad$ S1C: Saline water with $6 \mathrm{dsm}^{-1}$, with mulching.

S2UN: Saline water with $8 \mathrm{dsm}^{-1}$, without mulching. $\quad$ S2C: Saline water with $8 \mathrm{dsm}^{-1}$, with mulching.

Fig. (6) Schematic diagram of field design.

\section{RESULTS AND DISCUSSION}

\section{Water requirements of wheat crop:}

According to equation number (2), the crop evapotranspiration of wheat in this study was $394.31 \mathrm{~mm}$ per season and added water using by emission uniformity $(89.6 \%)$ is $440 \mathrm{~mm}$ per season. Wheat crop take 144 day to finished growth season cycle as shown in Fig. (7).

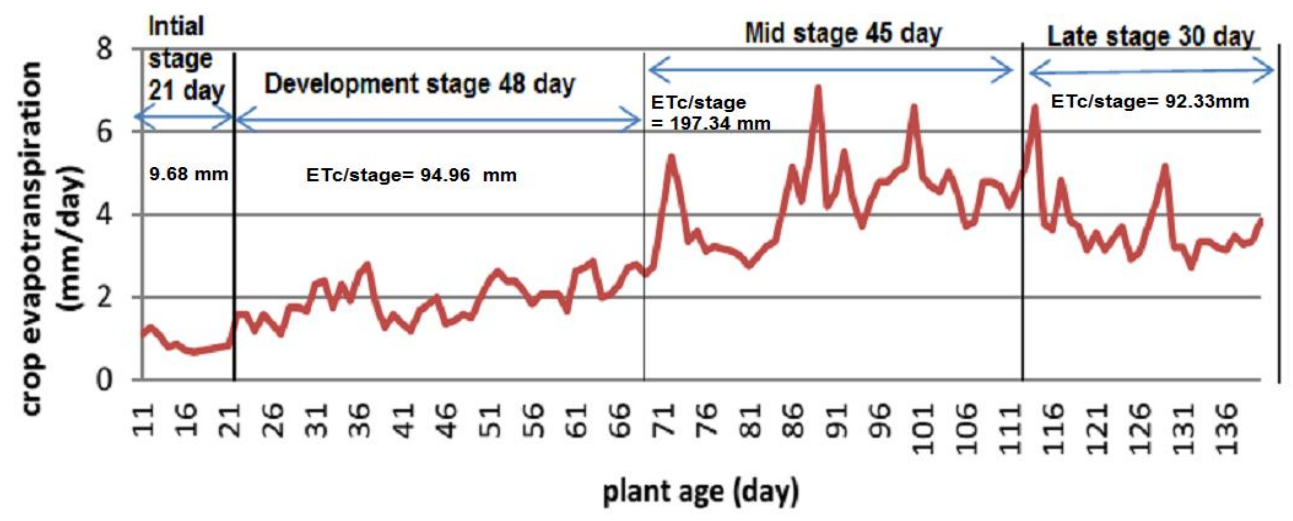

Fig. (7): Crop evapotranspiration data estimated according to center laboratory for agriculture climate (CLAC). 
Evaluation of emission uniformity (EU) of drip irrigation system as affected by salt accumulation after harvesting:

The EU of drip irrigation system was $89.6 \%$ at the beginning of the experimental work. Here after in Fig. (8). EU was calculated at the end of growing season to illustrate the effect of salt accumulation. Results show that as salinity increase the final EU decreases due to salt clogging.

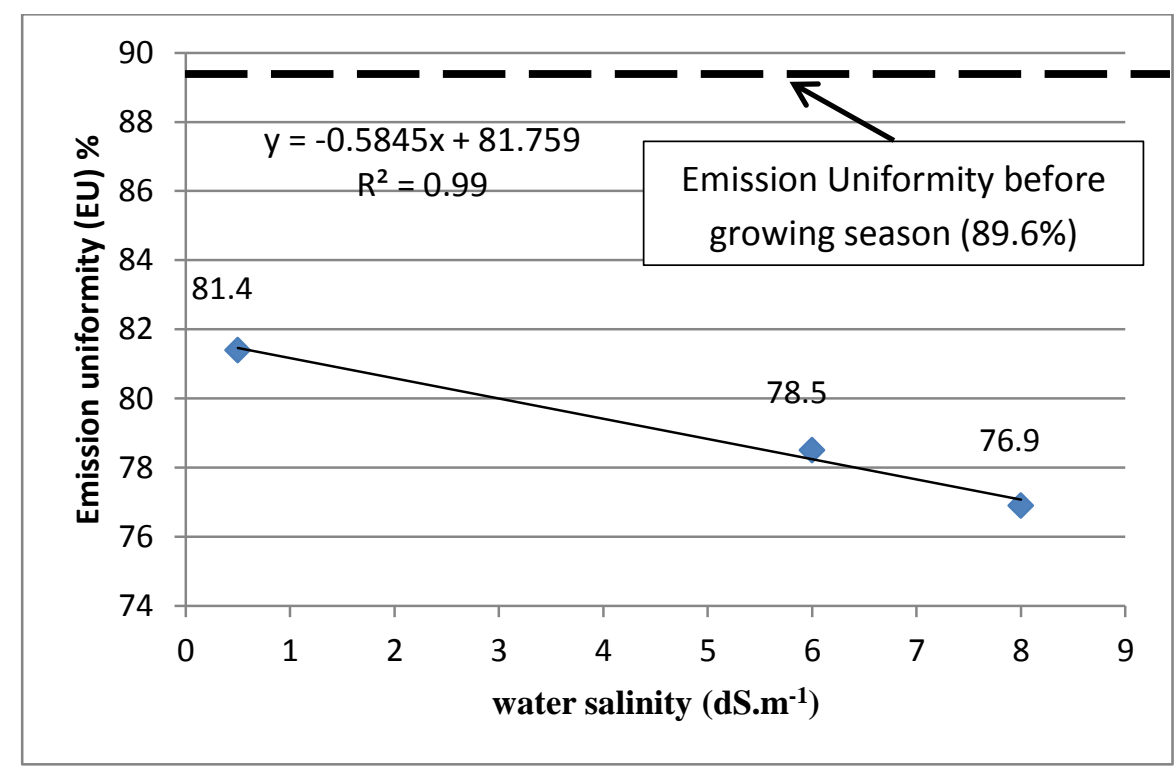

Fig. (8): Emission uniformity as affected by salt accumulation at the end of growing season of wheat crop.

\section{Effect of mulching and salinity on wheat yield:}

Wheat grain yield under fresh water treatments recorded (3366.5 and $3227.2 \mathrm{~kg} \mathrm{ha}^{-1}$ ) for non-mulching and mulching respectively. Under saline water $\left(6 \mathrm{dS} . \mathrm{m}^{-1}\right)$ treatments, wheat grain yield recorded (2411.6 and $\left.2936.4 \mathrm{~kg} \mathrm{ha}^{-1}\right)$ while under saline water $\left(8 \mathrm{dS} . \mathrm{m}^{-1}\right)$ treatments wheat grain yield recorded (2231.9 and $2573.1 \mathrm{~kg} \mathrm{ha}^{-1}$ ) as shown in Fig. (9). these results confirmed the effectiveness of mulching technique improving wheat yield. Thus, waters can be used successfully to grow crops under certain conditions (Dordipou et al., 2004). Using sea water and rice straw mulch, Zhang et al., (2008) showed that use of mulches significantly reduced ET of Swiss chard and also effectively reduced salt accumulation under high saline irrigation. High diluted sea water 
irrigation could be used under mulch condition without serious salinitydamage caused by salinity stress to Swiss chard.

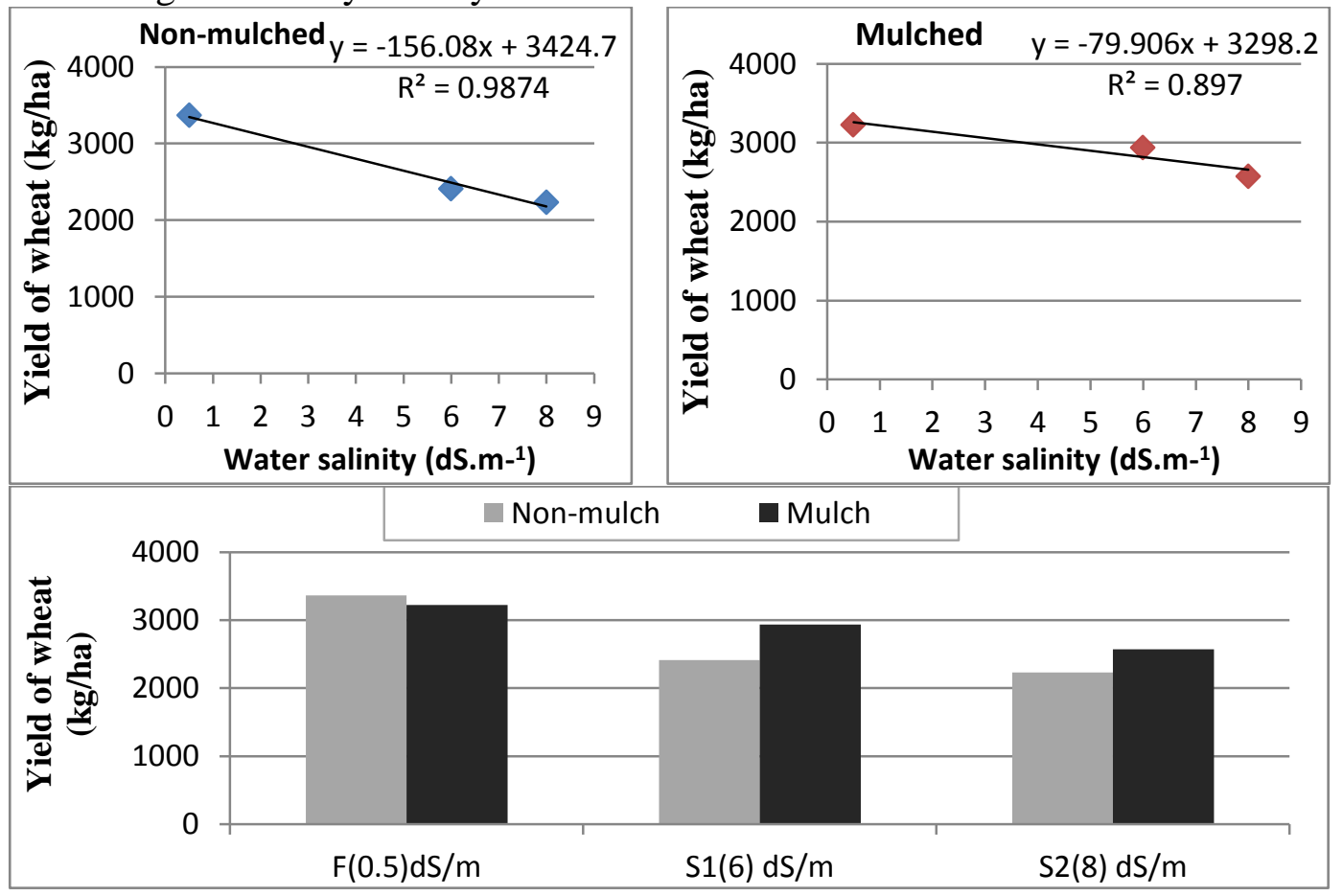

Fig. (9): Effect of Mulching and salinity treatments on wheat yield per hectare

Mansour et al., (2015) found that wheat productivity of variety Misr 2 under sprinkler irrigation system in sandy soil in Egypt was 1179.85, 1342.75 and $1379.30 \mathrm{~kg} \mathrm{ha}^{-1}$. Also, results almost agree with (Mojid et al., 2013) who used artificial saline water of electrical conductivity (EC) $0.385,7$ and 10 $\mathrm{dS} \mathrm{m}{ }^{-1}$ and found wheat grain yield $\left(3.85 \mathrm{t} \mathrm{ha}^{-1}, 3.683 \mathrm{tha}^{-1}\right.$ and $3.257 \mathrm{t}$ $\mathrm{ha}^{-1}$ ) respectively.

\section{Water use efficiency and harvest index:}

WUE and HI were calculated by using equations number (3\&4). WUE ranged from 0.57 to $0.85 \mathrm{~kg} \mathrm{~m}^{-3}$ under the irrigated treatments (Table 4). The highest WUE values were recorded with fresh water without mulching treatment and the lowest value was recorded with saline water $\left(8 \mathrm{dS} . \mathrm{m}^{-1}\right)$ without mulching. WUE in mulching and saline treatment was more pronounced than the non-mulching. The harvest index obtained in this study (0.28-0.47) under irrigated conditions. The harvest index in case in non-mulching treatments was much better than in mulching treatments. 


\begin{tabular}{|c|c|c|c|c|}
\hline Treatments & $\begin{array}{l}\text { Biomass } \\
\left(\mathrm{kg} \cdot \mathrm{ha}^{-1}\right)\end{array}$ & $\begin{array}{l}\text { Grain Yield } \\
\left(\mathrm{kg}^{\left.-\mathrm{ha}^{-1}\right)}\right.\end{array}$ & $\begin{array}{c}\text { Harvest } \\
\text { index }\end{array}$ & $\begin{array}{c}\text { WUE } \\
\left(\mathrm{kg} \cdot \mathrm{m}^{3}\right)\end{array}$ \\
\hline FUN & 9762 & 3367 & 0.35 & 0.85 \\
\hline $\mathrm{FC}$ & 11456 & 3227 & 0.28 & 0.82 \\
\hline $\mathrm{S}_{1} \mathrm{UN}$ & 5325 & 2412 & 0.45 & 0.61 \\
\hline $\mathrm{S}_{1} \mathrm{C}$ & 8122 & 2936 & $0 . r 4$ & $0 .^{\vee} 5$ \\
\hline $\mathrm{S}_{2} \mathrm{UN}$ & 4775 & 2232 & 0.47 & 0.57 \\
\hline $\mathrm{S}_{2} \mathrm{C}$ & 6122 & 2573 & $0 . \leqslant Y$ & 0.75 \\
\hline
\end{tabular}

In this respect, Kang et al., (2002) demonstrated that WUE was ranged from 0.77 to $1.46 \mathrm{~kg} . \mathrm{m}^{3}$ under the irrigated treatments and harvest index from 0.25-0.45. A good yield of spring wheat under irrigation was 4 to 6 ton /ha and the water utilization for wheat grain yield about 0.8 to $1 \mathrm{~kg} . \mathrm{m}^{3}$ (Doorenbos and Kassam, 1979).

Effect of mulching and salinity on growth parameters:

\section{1-Plant height of wheat crop:}

Results show that mulching can enhance plant height in all growth stage (initial, development and mid stage) of wheat crop under fresh water and saline water conditions, as shown in Figs. (10, 11 and 12). These results are compatible with the results obtained from soil wettability Figs. (13.1, 13.2 and 13.3) for mulched treatments (FC, $\left.S_{1} C, S_{2} C\right)$.

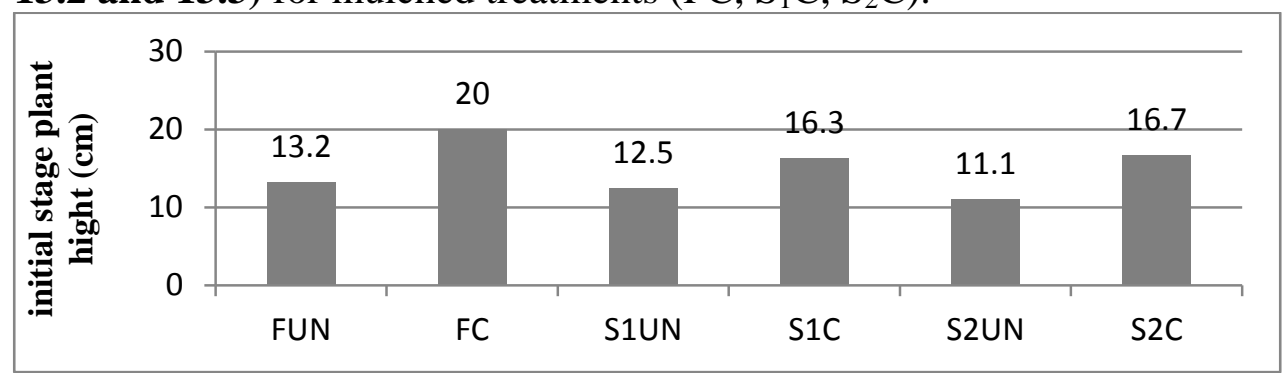

Fig. 10: Effect of mulching on plant height of wheat crop in initial stage.

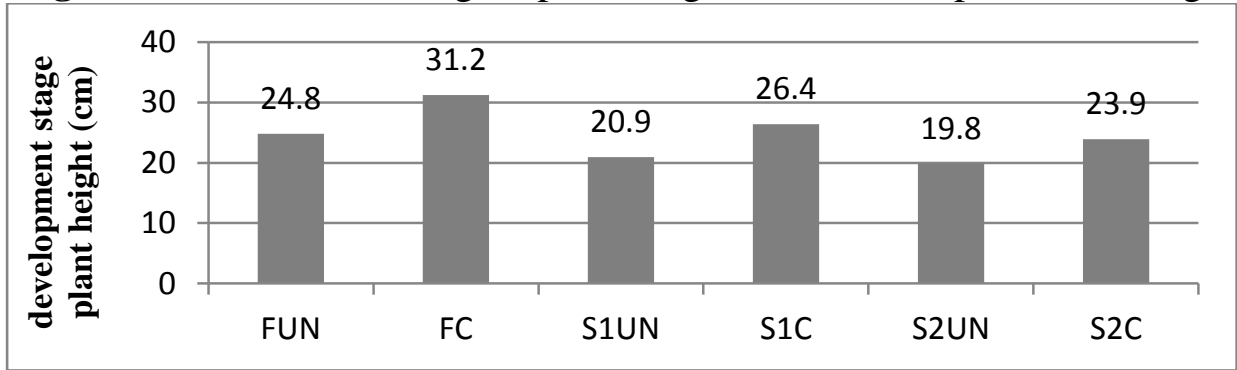

Fig. 11: Effect of mulching on plant height of wheat crop in development stage. 


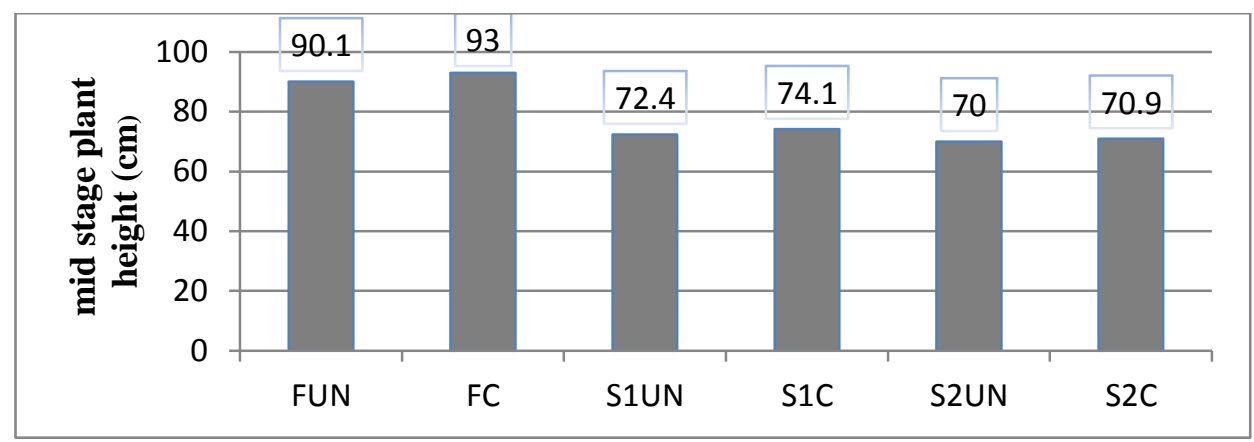

Fig. 12: Effect of mulching on plant height of wheat crop in mid stage.

\section{Evaluation of soil salinity during the growing season:}

Salt accumulation around wheat season in sandy soil after $(24,71,114$ and 143 day) after sowing by using mean of summation of salt accumulation in soil layers $(15,30,50,70$ and $90 \mathrm{~cm})$ to show the saline stress that plant combat around growth season . Fig. (13) illustrated that mulching reduce the effect of water salinity $S_{1}$ and $S_{2}$ in mid and late stages of wheat.

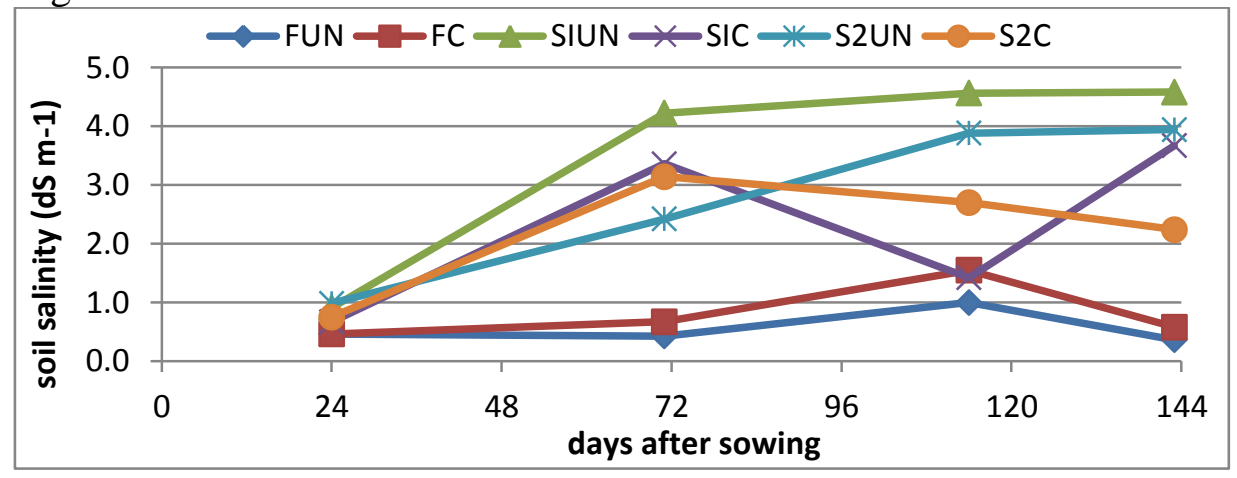

Fig. (13): Effect of mulching on soil salinity.

Effect of mulching on soil water content within the soil profile in all treatments on mid stage:

The measurements taken by (NMM) allowed deducing the soil wettability in addition; one can distinguish between both mulched and mulching treatments. Soil moisture contents were determined after irrigation and the before next irrigation, Calculating soil moisture depletion, this is due to surface evaporation and transpiration of wheat plant. For instant, under fresh water treatment, results indicated that soil sustains high moisture content in those plots with rice straw mulching in 
comparison to those plots without mulching. This trend was noted for all treatments covered with rice straw, which reflect the role of mulching in keeping soil moisture for long time which helps wheat crop to cape with stresses. As shown in Figs. (14.1, 14.2 and 14.3).

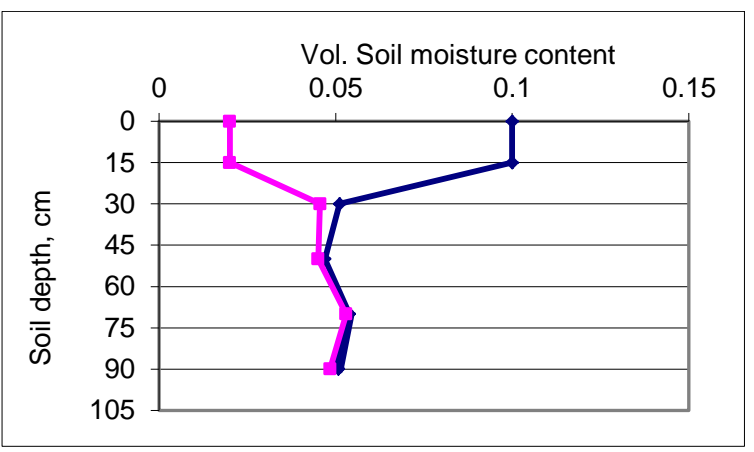

Fig.(14.1)

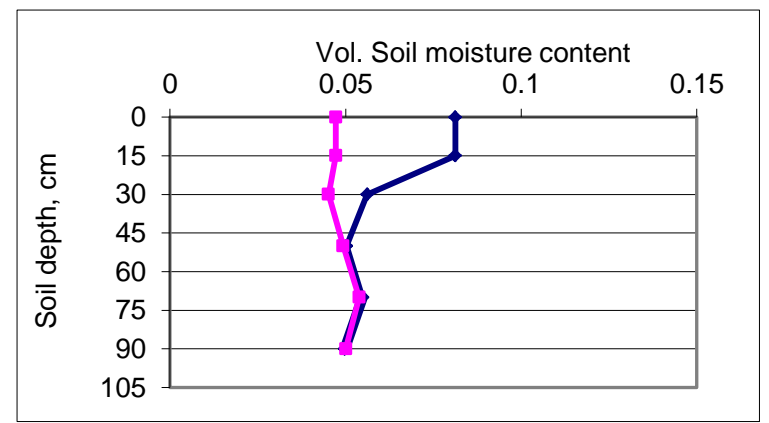

Fig.(14.2)

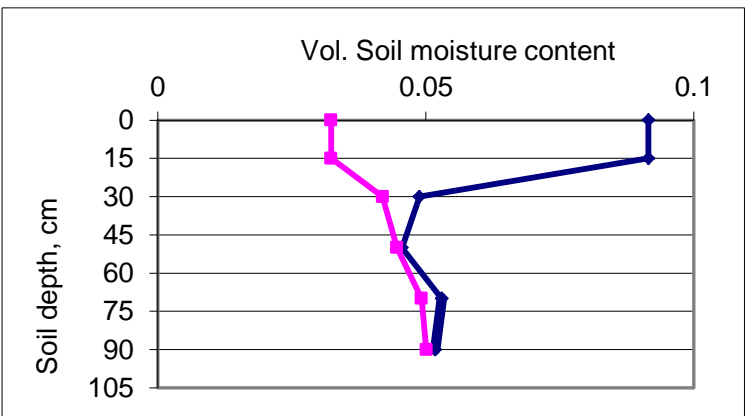

Fig.(14.3)

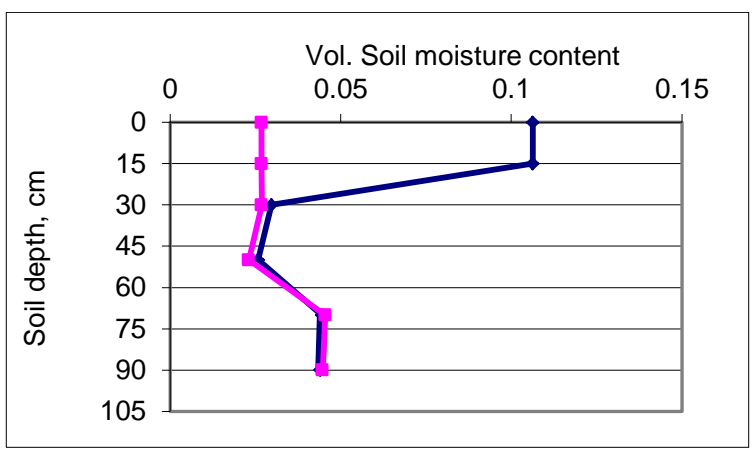

FC

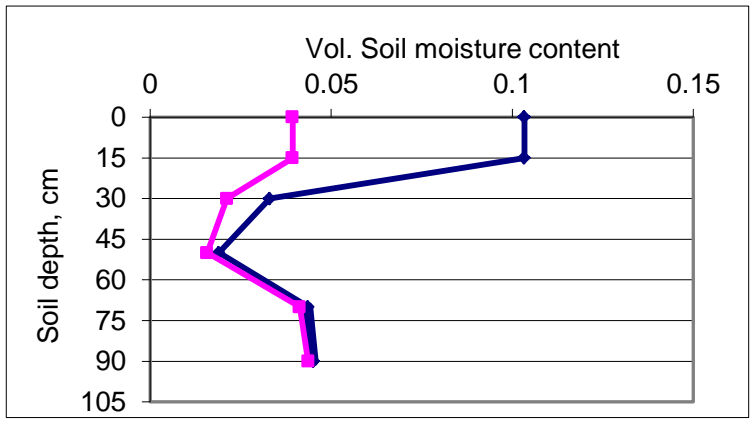

S1C

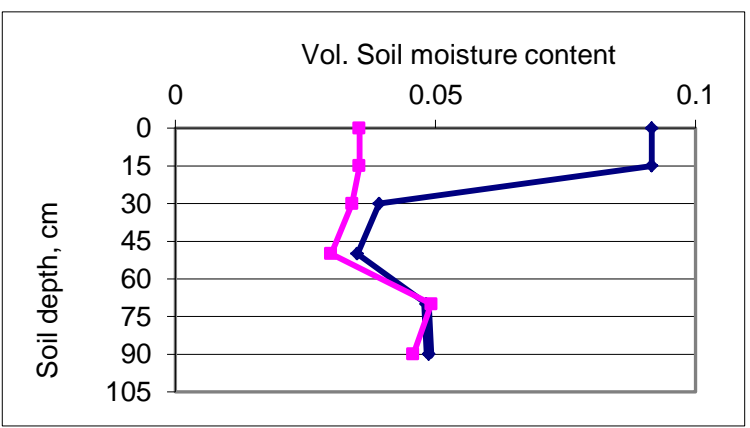

$\mathrm{S} 2 \mathrm{C}$

Fig. (14): Soil water distribution within the soil profile in mid stage of wheat crop under mulching and non-mulching conditions. 


\section{CONCLUSION}

In the present study, principal effects of rice straw mulch were to reduce soil evaporation and soil sustains high moisture content with rice straw mulching in comparison to without mulching, mulching increase the wheat ability to combat salinity stress and tend to improve wheat growth and yield under saline irrigation and reduce in overall salts accumulation, also, under saline irrigation mulching has a positive effect on water use efficiency. The highest WUE values were recorded with fresh water without mulching and the lowest value was recorded with saline irrigation water $\left(8 \mathrm{dS} . \mathrm{m}^{-1}\right)$ without mulching. Mulch strategy was recommended for higher wheat production based on most of growth parameters and also for being organic in nature.

\section{REFERANCE}

Ali, M.; L. Ali; M. Sattar and M. A. Ali (2010). Improvement in Wheat (Triticum aestivum L.) Yield by Manipulating Seed Rate and Row Spacing in Vehari Zone. The Journal of Animal and Plant Sciences, 20(4): 225-230.

Allen, R. G.; L. S. Pereira; D. Raes and M. Smth (2006). Crop Evapotranspiration, guidelines for computing crop water requirements. FAO Irrigation and Drainage Paper No.56. Food and Agriculture Organization of the United Nations, Rome, Italy.

Aragüés, R. and E. Teresa (2014). Effectiveness of inorganic and organic mulching for soil salinity and sodicity control in a grape vine orchard drip-irrigated with moderately saline waters. Instituto Nacional de Investigación Tecnología Agraria Alimentaria (INIA). Spanish Journal of Agricultural Research, 12(2): 501-508.

Carter, M. R. and E. G. Gregorich (2008). Soil Sampling and Methods of Analysis. (2nd ed.), CRC Press Taylor \& Francis Group, 6000 Broken Sound Parkway NW, Suite 300 Boca Raton, FL, p. 1224.

Dayyoub, A.; A. Hamdy; N. Katerji and M. Mastrorilli (2007). Water saving potentialities through the use of saline water and the application of deficit irrigation. CIHEAM,Options Méditerranéennes: Série B. Etudes et Recherches; No. 56 Vol. II: 45- 59. 
Doorenbos, J. and A. H. Kassam (1979). Yield response to water. FAO Irrigation and Drainage Paper 33, FAO, Rome, Italy.

Dordipour, I.; H. Ghadiri; M. Bybordi; H. Siadat; M. J. Malakouti and J. Hussein (2004). The Use of Saline Water from the Caspian Sea for Irrigation and Barley Production in Northern Iran . International Soil Conservation Organization Conference Brisbane. Paper No. 986.

El-Shabrawi, H. M.; B. A. Bakry; M. A. Ahmed and M. A. El-Lail (2015). Humic and Oxalic Acid Stimulates Grain Yield and Induces Accumulation of Plastidial Carbohydrate Metabolism Enzymes in Wheat Grown under Sandy Soil Conditions. Agricultural Sciences, 6: $175-185$.

FAO (2012). Country Programming Framework (CPF) Government of Egypt 2012-2017.

Gaber, A. M. (2000). Water consumptive use, water use efficiency and production of some Wheat varieties. Egypt .J. Sci., 40 (4): 545-556.

Hamdy, A. (2005). The use of non-conventional water resources. Options Méditerranéennes, Séries A n. 66, Proceedings of the international Workshop Alger, Algeria.

IAEA (2008). Field estimation of soil water content: practical guide to methods, Instrumentation and Sensor Technology. Training course series 30 Vienna.

Kang, S.; L. Zhang; Y. Liang and H. Cai (2002). Effects of Limited Irrigation on Yield and Water Use Efficiency of Winter Wheat on the Loess Plateau of China. ACIAR Monograph No. 84, 105-116.

Mansour, H. A.; M. E. El-Hagarey; A. Saad; A. A. A. Ibrahim and V. F. Bralts (2015). Management of Sprinkler Irrigation System and Different Egyptian Wheat Varieties for Uniformity, Yield and Water Productivity.European Journal of Academic Essays, 2(6): 1-6.

Merriam, J. L. and J. Keller (1978). Farm Irrigation System Evaluation: a guide for management. UTAH State University. Logan, Utah, USA. 
Mojid, M. A.; K. F. I. Murad; S. S. Tabriz and G. C. L. Wyseure (2013). An advantageous level of irrigation water salinity for wheat cultivation. J. Bangladesh Agril. Univ. 11(1): 141-146.

Sarwar, M. A.; N. Akbar; H. M. R. Javeed; M. A. Shehzad; A. Mehmood and H. T. Abbas (2013). Response of Zero Tilled Wheat Crop to Different Mulching Techniques in a Semiarid Environment. International Journal of Advanced Research., 1, Issue. 9:768-776.

Shenkut, A.; K. Tesfaye; F. Abegaz and T. Hordofa (2013). Determination of Water Requirement and Crop Coefficient for Sorghum (Sorghum bicolor L.) at Melkassa, Ethiopia. East African Journal of Sciences, 7 (1): 41-50.

Yamanaka, T.; M. Inoue and I. Kaihotsu (2004). Effects of gravel mulch on water vapor transfer above and below the soil surface. Agric. Water Manage.67:145-155.

Yazar, A.; A. Hamdy; B. Gencel and M. Sezen (2015). Corn yield response to saline irrigation water applied with atrickle system. Researchgate, http://www.researchgate.net/publication/265242964

Zhang, Q. T.; M. Inoue; K. Inosako; M. Irshad; K. Kondo; G. Y. Qiu and S. P. Wang (2008). Ameliorative effect of mulching on water use efficiency of Swiss chard and salt accumulation under saline irrigation. Journal of Food, Agriculture \& Environment Vol. 6 (3\&4): 480-485.

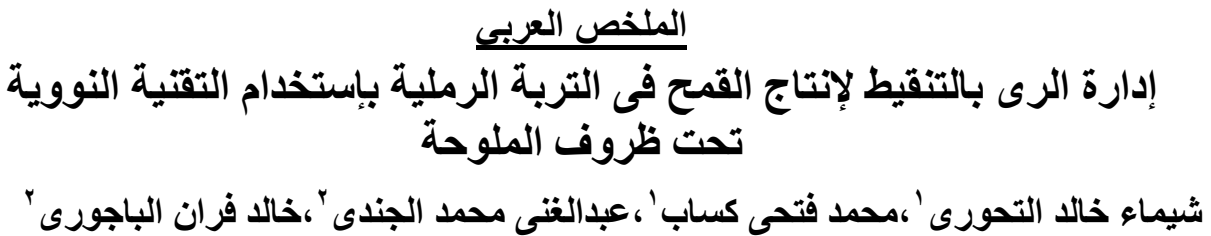
أجريت تجربة حقلية بالمزرعة التجريبة بقسم بحوث الأراضى والمياة التابعة لمركز البحوث

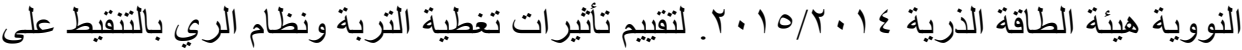

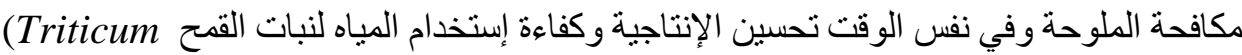
دaestivum L.)

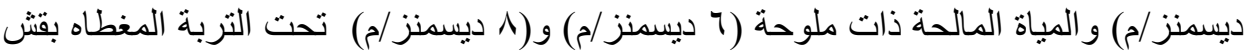

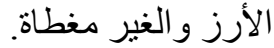
r ق بم الهندسة الزراعية، كلية الزراعة، جامعة عين شمس. 
تم رى كل معاملة مرتين بالإسبوع وكانت كمية المياه الكلية المضافة على مدار الموسم . ع

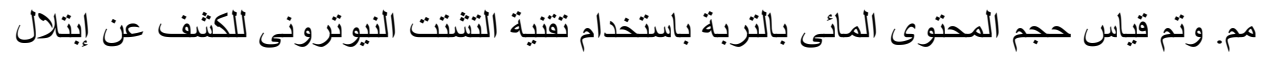

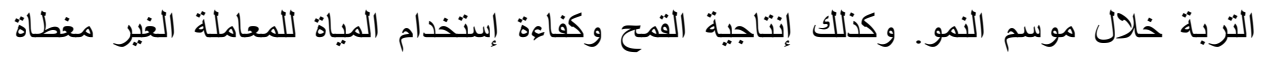

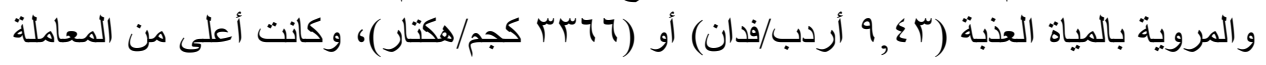

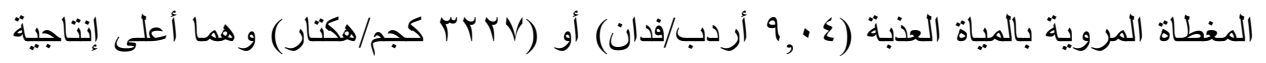

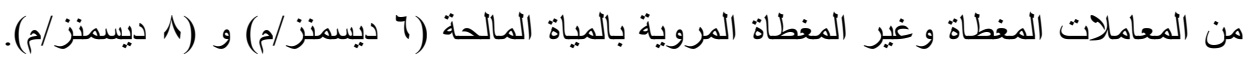
تحت الري بالمياه المالحة كانت إنتاجية القمح وكفاءة استخدام المياه فى المعاملات المغناة المغطاة

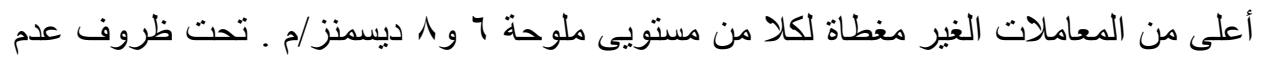

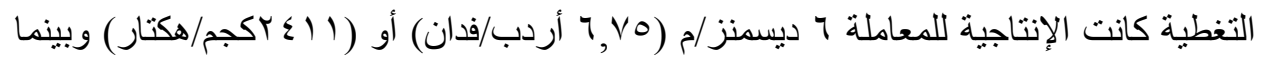

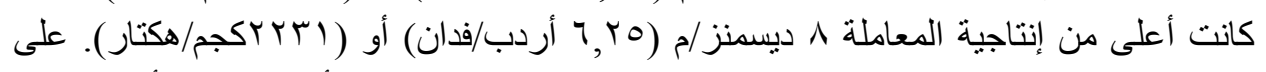

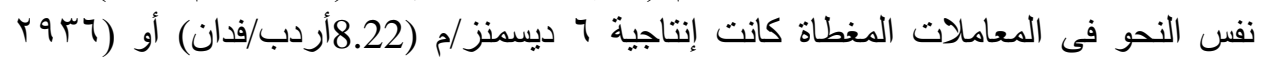

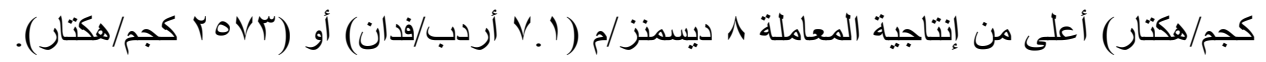
كما أشارت النتائج المذكورة أعلاه أن تغطية سطح التربة يمكن أن تحسن نمو و إنتاجية محصول

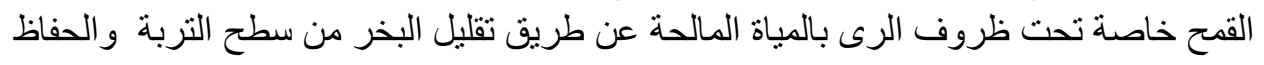
على رطوبة التربة التي تعزز قدرة القمح لتحمل الملوحة. 